\title{
Distinct Pattern of Endoplasmic Reticulum Protein Processing and Extracellular Matrix Proteins in Functioning and Silent Corticotroph Pituitary Adenomas
}

\author{
Alexander K. Eieland ${ }^{1,2,+}{ }^{\dagger}$ Kjersti R. Normann ${ }^{1,2,3, \dagger}{ }^{+}$Arvind Y. M. Sundaram ${ }^{4}$, \\ Tuula A. Nyman ${ }^{3,5}$ D, Kristin A. B. Øystese ${ }^{1,3}$, Tove Lekva ${ }^{2}$, Jens P. Berg ${ }^{3}$, Jens Bollerslev ${ }^{1,3}$ and \\ Nicoleta C. Olarescu 1,2,3,* \\ 1 Section of Specialized Endocrinology, Department of Endocrinology, Oslo University Hospital (OUS), \\ 0424 Oslo, Norway; aleeie@ous-hf.no (A.K.E.); k.r.normann@medisin.uio.no (K.R.N.); \\ k.a.oystese@medisin.uio.no (K.A.B.Ø.); jens.bollerslev@medisin.uio.no (J.B.) \\ 2 Research Institute for Internal Medicine, Oslo University Hospital (OUS), 0372 Oslo, Norway; \\ Tove.Lekva@rr-research.no \\ 3 Institute of Clinical Medicine, Faculty of Medicine, University of Oslo, 0318 Oslo, Norway; \\ t.a.nyman@medisin.uio.no (T.A.N.); j.p.berg@medisin.uio.no (J.P.B.) \\ 4 Department of Medical Genetics, University of Oslo, Oslo University Hospital (OUS), 0450 Oslo, Norway; \\ arvind.sundaram@medisin.uio.no \\ 5 Department of Immunology, Oslo University Hospital (OUS), 0424 Oslo, Norway \\ * Correspondence: n.c.olarescu@medisin.uio.no \\ + These authors contributed equally to this work.
}

Received: 5 August 2020; Accepted: 5 October 2020; Published: 14 October 2020

Simple Summary: Corticotroph pituitary adenomas present a spectrum of functionality regarding hormonal production, ranging from functioning to silent tumors. Moreover, they show different invasiveness and recurrent behavior profiles, the silent being considered an aggressive type of adenomas. Through analyses of global transcriptome and proteome, we show that both groups expressed genes and protein related to protein synthesis and vesicular transport, and present a distinct pattern of collagen/ extracellular matrix proteins. Endoplasmic reticulum protein processing is a key factor for hormone production in functioning corticotroph adenomas. Furthermore, a distinct cell adhesion profile in silent corticotroph adenomas may explain the aggressive behavior. Together, our findings shed light on the different repertoires of activated signaling pathways in corticotroph pituitary adenomas and may reveal new potential medical targets.

\begin{abstract}
Functioning (FCA) and silent corticotroph (SCA) pituitary adenomas act differently from a clinical perspective, despite both subtypes showing positive TBX19 (TPIT) and/or adrenocorticotropic hormone (ACTH) staining by immunohistochemistry. They are challenging to treat, the former due to functional ACTH production and consequently hypercortisolemia, and the latter due to invasive and recurrent behavior. Moreover, the molecular mechanisms behind their distinct behavior are not clear. We investigated global transcriptome and proteome changes in order to identify signaling pathways that can explain FCA and SCA differences (e.g., hormone production vs. aggressive growth). In the transcriptomic study, cluster analyses of differentially expressed genes revealed two distinct groups in accordance with clinical and histological classification. However, in the proteomic study, a greater degree of heterogeneity within the SCA group was found. Genes and proteins related to protein synthesis and vesicular transport were expressed by both adenoma groups, although different types and a distinct pattern of collagen/extracellular matrix proteins were presented by each group. Moreover, several genes related to endoplasmic reticulum protein processing were overexpressed in the FCA group. Together, our findings shed light on the different repertoires of activated signaling pathways in corticotroph adenomas, namely, the increased protein processing capacity of FCA and a specific pattern of adhesion molecules that may play a role in the aggressiveness of SCA.
\end{abstract}


Keywords: RNA sequencing; proteomics; cell adhesion; endoplasmic reticulum protein folding

\section{Introduction}

Non-functioning pituitary adenomas (NFPAs) comprise up to a half of all pituitary neuroendocrine tumors (PitNETs) [1,2], and although they are characterized as silent, patients present increased morbidity and decreased quality of life due to clinical manifestations caused by the tumor pressure $[3,4]$. The latest World Health Organization (WHO) classification using immunohistochemistry (IHC) for transcription factors and anterior pituitary hormones illustrates that the most common NFPA subtype is the silent gonadotroph followed by the silent corticotroph adenoma (SCA) [5]. SCA comprise $5-19 \%$ of the NFPAs, depending on the cohort, and approximately $3 \%$ of all adenomas, whereas their functional counterpart, functioning corticotroph pituitary adenoma (FCA), represent only $2-6 \%[1,2,6,7]$. SCA is categorized as a potentially more aggressive neuroendocrine tumor posing a high risk of increased invasiveness and parasellar growth, a tendency for multiple and earlier recurrences, and higher rates of hemorrhage and apoplexy [8-12]. Conversely, its clinically active counterpart rarely poses challenges due to tumor volume. Due to the presence of clinical symptoms, FCA is discovered at an earlier stage in tumor development, most often as a microadenoma located in the sellar area (in 80\% of cases) [13], whereas SCA present as a macroadenoma with extrasellar expansion at the time of diagnosis [14]. Efforts to explain the aggressiveness and the propensity for recurrence of SCA as compared to FCA are, to date, limited and inconclusive [15].

There is a spectrum of functionality of the corticotroph adenoma ranging from totally silent to whispering, and finally to clinically functioning corticotroph adenoma [5]. The molecular mechanism behind the silence of the SCA is yet to be unveiled, though several hypotheses have been proposed.

For example, it has been proposed that SCA presents a dysfunctional processing of ACTH from its precursor protein pro-opiomelanocortin (POMC), whereby a variety of ACTH precursors are secreted $[10,13,14,16,17]$. POMC is cleaved by different enzymes into a variety of peptides in a tissue-dependent manner [18]. Among these, prohormone convertases, PCSK1 and PCSK2, were shown to have defective expression in SCA, perhaps contributing to the diminished ACTH production $[14,19]$.

Another hypothesis postulates that SCA may contain incompletely differentiated precursors of corticotroph cells, not yet capable of secreting bioactive hormones. This has been reinforced by their lower expression of both the corticotroph transcription factor, TBX19, POMC, and some adenomas showing poor and immature differentiation [13]. Less differentiated corticotroph cells as described in SCA might also imply that their secretory machinery is deficient or immature. Indeed, in patients with SCA, plasma ACTH levels do not correlate with the number of ACTH-positive cells of tumors, suggesting an altered secretion of an intact/biological active ACTH molecule [16].

Finally, another theory involves the role of tissue specific transcription regulators of POMC expression [20].

We here hypothesize that the mechanism involved in "the silencing" of SCA is multifactorial and involves disturbed transcription and processing of POMC, leading to an altered production and deficient secretion of modified ACTH molecules. Furthermore, there are clinical differences between SCA and FCA regarding their growth potential, and comparing their molecular profiles could reveal molecular targets that explain the increased aggressiveness of SCA.

The present study aims to investigate the differences between FCA and SCA by performing transcriptomics and proteomics analyses, followed by pathway discovery. The focus was to find the differences regarding hormone production and secretion (and possible medical treatment targets), and biomarkers of tumor growth and aggressiveness. 


\section{Results}

\subsection{Clinical Characteristics of Patients with FCA and SCA}

Clinical characteristics of patients are presented in Table S1. No significant difference was found in age, gender and Ki67-index between the two groups. Cortisol levels were higher in the FCA group $(p=0.007)$, as expected. Additionally, tumor size was significantly larger for the SCA group $(p=0.002)$ (Table S1 and Figure S1).

FCA expressed higher mRNA levels of POMC, TBX19 and PCSK1 than SCA (Figure 1A). However, there was an overlap in the expression of these corticotroph cell markers, several FCA tumors showing low levels, similar to those presented in SCA.
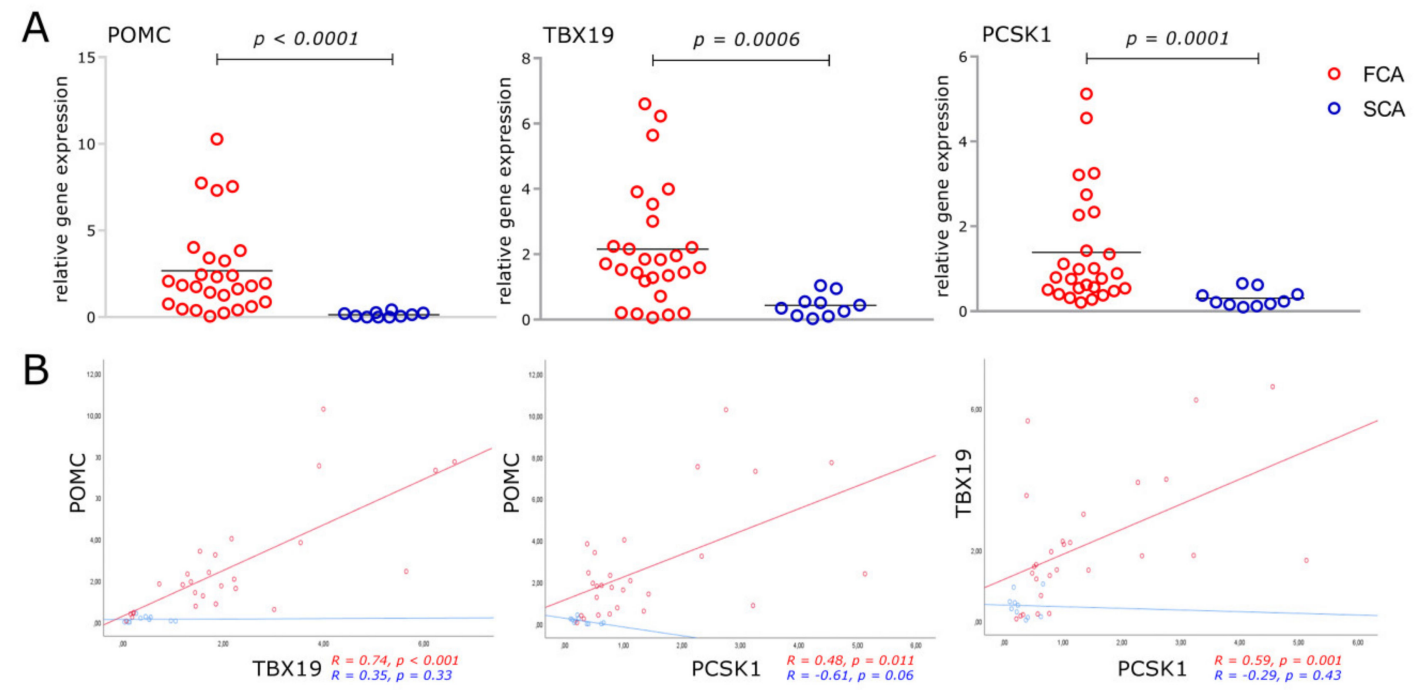

Figure 1. mRNA expression of POMC, TBX19 and PCSK1 in functioning (FCA) and silent (SCA) corticotroph adenomas. Data are presented as a scatter dot plot and mean (A) and correlation plots with linear regression lines $(\mathbf{B})$. A Mann-Whitney nonparametric test and Spearman correlation were performed; FCA $n=27$; SCA $n=10$;

Gene expression of POMC was strongly associated with TBX19 $(R=0.74, p<0.001)$ and PCSK1 $(R=0.48, p=0.01)$ in FCA, but no significant association was observed in the SCA group (Figure 1B). TBX19 was also positively associated with PCSK1 in FCA $(R=0.59, p=0.001)$, but not in SCA.

\subsection{RNA-seq}

Bioinformatics analyses revealed 631 differentially expressed genes (DEGs; fold change $>1.8$ and $q<0.05)$. Of these, 286 DEGs were up-regulated and 345 down-regulated in FCA as compared to SCA. Heatmap analyses with hierarchical clustering and principal component analysis (PCA) analyses showed that samples grouped according to their tumor type in FCA and SCA without discrepancies (Figure 2A,C). Samples that clustered together presented a more similar gene expression profile. 

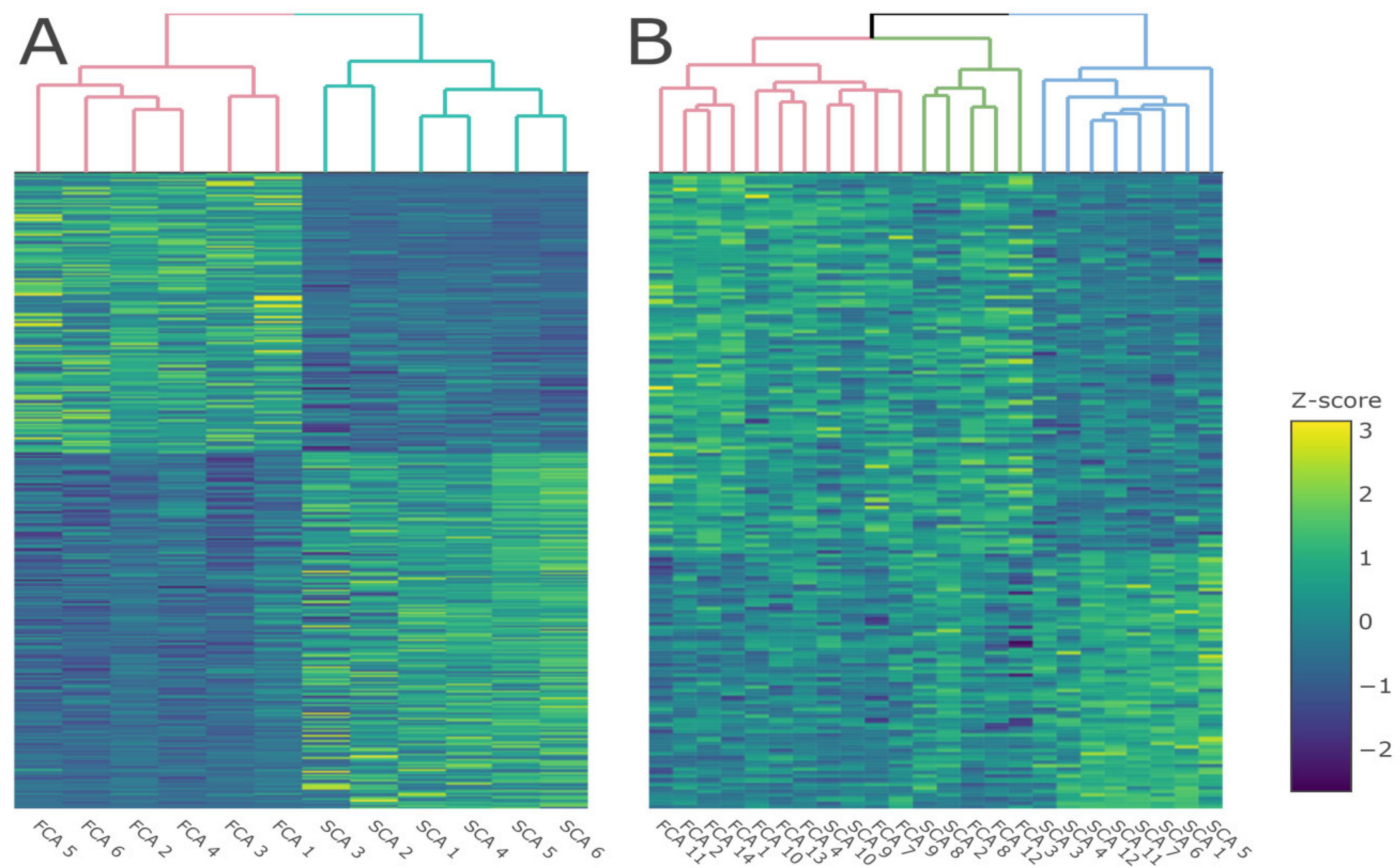

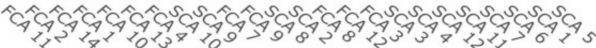
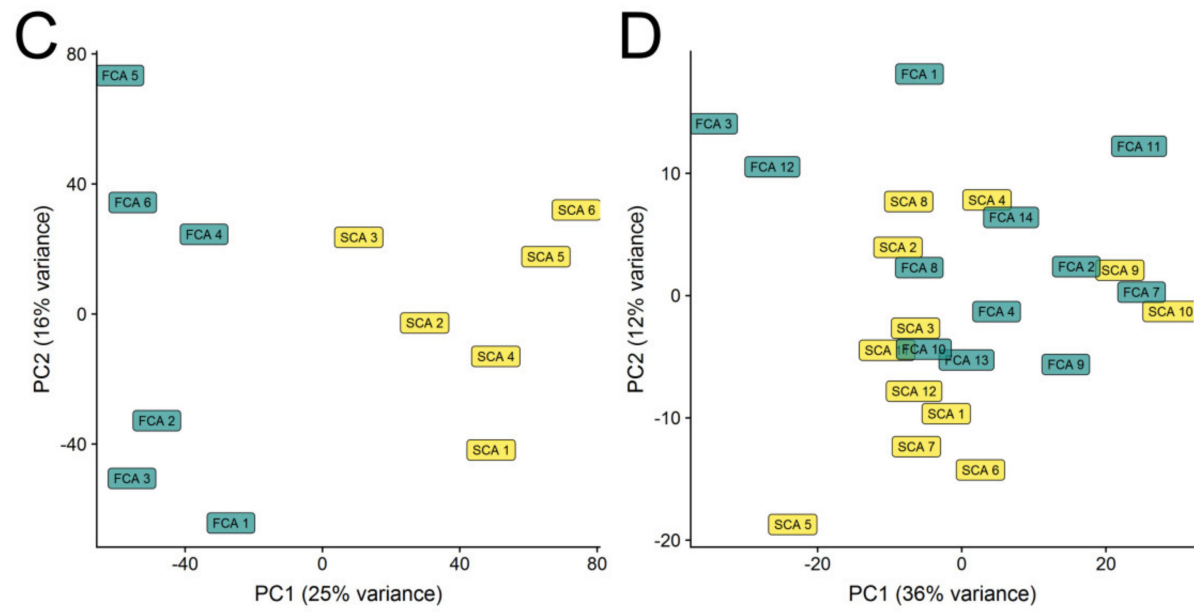

Figure 2. Heatmap (A,B) and principal component analysis (PCA; C,D) profiling of RNA-seq differentially expressed genes (DEGs; $\mathbf{A}, \mathbf{C}$ ) and proteomic differentially expressed proteins (DEPs; B,D) in functioning (FCA) and silent (SCA) corticotroph adenomas.

\subsection{Quantitative Label-Free Proteomics}

Proteomic analysis identified 2782 proteins; among them, 170 were differentially expressed proteins (DEPs; fold change $>1.6$ and $p<0.05$ ) with 102 DEPs up-regulated and 68 DEPs were down-regulated in FCA as compared to SCA. Heatmap analyses with hierarchical clustering (Figure 2B) showed a more heterogeneous separation of the tumors. Several silent adenomas (SCA_10, SCA_9, SCA_8 and SCA_2) presented a protein expression profile more alike to FCA. No clinical particularities were observed for these four patients, although patient SCA_8 had a high plasma ACTH level, $14.7 \mathrm{pmol} / \mathrm{L}$ (normal range $<10.2$ ), with normal serum cortisol, $477 \mathrm{nmol} / \mathrm{L}$ (normal range 112-502). and no clinical signs of hypercortisolemia. Furthermore, 8 of the 12 SCA tumors grouped together. The PCA plot (Figure 2D) showed more blunted separation of the two groups as compared to RNA-seq.

\subsection{Common Molecules Presented in Transcriptomics and Proteomics Studies}

Comparison of the differentially expressed genes and protein lists showed 38 differentially expressed molecules at both the mRNA and protein expression level (Table 1). 
Table 1. Common molecules presented in transcriptomics and proteomics studies. Thirty-eight molecules were differentially expressed at both mRNA and protein level in functioning (FCA) and silent (SCA) corticotroph adenomas. Molecules up-regulated in FCA are presented with positive fold of change values.

\begin{tabular}{|c|c|c|c|c|}
\hline Gene Short Name & Gene Description & Cell Adhesion & RNA-seq Fold Change & Proteomics Fold Change \\
\hline GH1 & growth hormone 1 & & 1982.1 & 18.1 \\
\hline PRL & prolactin & & 176.1 & 19.8 \\
\hline POMC & proopiomelanocortin & & 33.3 & 9.7 \\
\hline LGALS3 & galectin 3 & $x$ & 22.8 & 7.7 \\
\hline ELN & elastin & & 14.3 & 1.9 \\
\hline KRT18 & keratin 18 & $x$ & 13.1 & 9.6 \\
\hline CACNA2D2 & $\begin{array}{c}\text { calcium voltage-gated } \\
\text { channel auxiliary subunit } \\
\text { alpha2delta } 2\end{array}$ & & 8.7 & 3.5 \\
\hline ENPP2 & $\begin{array}{c}\text { ectonucleotide } \\
\text { pyrophosphatase/ } \\
\text { phosphodiesterase } 2\end{array}$ & $x$ & 6.0 & 5.2 \\
\hline DKK3 & $\begin{array}{c}\text { dickkopf WNT signaling } \\
\text { pathway inhibitor } 3\end{array}$ & & 5.4 & 7.6 \\
\hline ANXA11 & annexin A11 & & 5.1 & 3.3 \\
\hline LAMA4 & laminin subunit alpha 4 & $x$ & 4.9 & 2.6 \\
\hline MAOA & monoamine oxidase $\mathrm{A}$ & & 4.5 & 2.9 \\
\hline MFGE8 & $\begin{array}{l}\text { milk fat globule-EGF } \\
\text { factor } 8 \text { protein }\end{array}$ & & 4.5 & 9.0 \\
\hline $\mathrm{ACE}$ & $\begin{array}{c}\text { angiotensin I } \\
\text { converting enzyme }\end{array}$ & & 4.4 & 2.7 \\
\hline $\mathrm{DCN}$ & decorin & $x$ & 4.2 & 6.6 \\
\hline CALB1 & calbindin 1 & & 3.9 & 10.2 \\
\hline TBX19 & T-box 19 & & 3.8 & 4.9 \\
\hline SORBS2 & $\begin{array}{l}\text { sorbin and } \mathrm{SH} 3 \text { domain } \\
\text { containing } 2\end{array}$ & & 3.3 & 3.4 \\
\hline KCTD12 & $\begin{array}{c}\text { potassium channel } \\
\text { tetramerization domain } \\
\text { containing } 12\end{array}$ & & 2.7 & 2.5 \\
\hline APMAP & $\begin{array}{l}\text { adipocyte plasma membrane } \\
\text { associated protein }\end{array}$ & & 2.6 & 1.9 \\
\hline LTBP3 & $\begin{array}{l}\text { latent transforming growth } \\
\text { factor beta binding protein } 3\end{array}$ & & 2.5 & 4.1 \\
\hline GNAS & GNAS complex locus & & 2.3 & 1.9 \\
\hline MAT2A * & $\begin{array}{c}\text { methionine } \\
\text { adenosyltransferase 2A }\end{array}$ & & -2.5 & 1.7 \\
\hline LASP1 & LIM and $\mathrm{SH} 3$ protein 1 & $x$ & -2.5 & -2.4 \\
\hline CAB39L & $\begin{array}{l}\text { calcium binding } \\
\text { protein } 39 \text { like }\end{array}$ & & -2.7 & -3.1 \\
\hline CSRP1 & $\begin{array}{l}\text { cysteine and glycine } \\
\text { rich protein } 1\end{array}$ & & -3.0 & -2.9 \\
\hline QPCT & $\begin{array}{l}\text { glutaminyl-peptide } \\
\text { cyclotransferase }\end{array}$ & & -3.1 & -3.5 \\
\hline CLU & clusterin & $x$ & -3.9 & -3.5 \\
\hline
\end{tabular}


Table 1. Cont.

\begin{tabular}{ccccc}
\hline Gene Short Name & Gene Description & Cell Adhesion & RNA-seq Fold Change & Proteomics Fold Change \\
\hline S100A11 & $\begin{array}{c}\text { S100 calcium binding } \\
\text { protein A11 }\end{array}$ & $X$ & -4.2 & -5.7 \\
\hline DBI & $\begin{array}{c}\text { diazepam binding inhibitor, } \\
\text { acyl-CoA binding protein }\end{array}$ & & -4.5 & -4.2 \\
\hline PDLIM1 & PDZ and LIM domain 1 & $X$ & -5.2 & -5.3 \\
\hline FAM107B & $\begin{array}{c}\text { family with sequence } \\
\text { similarity 107 member B }\end{array}$ & -5.9 & -2.8 \\
\hline SLC32A1 & $\begin{array}{c}\text { solute carrier family 32 } \\
\text { member 1 }\end{array}$ & X & -7.2 & -4.5 \\
\hline GPC4 & glypican 4 & -8.6 & -3.0 \\
\hline EDIL3 & $\begin{array}{c}\text { EGF like repeats and } \\
\text { discoidin domains 3 }\end{array}$ & $\mathrm{X}$ & -8.7 & -6.7 \\
\hline CRABP2 & $\begin{array}{c}\text { cellular retinoic acid } \\
\text { binding protein 2 }\end{array}$ & $\mathrm{X}$ & -9.9 & -8.7 \\
\hline LAMC2 & laminin subunit gamma 2 & -12.9 & -9.6 \\
\hline NTS & neurotensin & -45.6 & -46.6 \\
\hline
\end{tabular}

${ }^{*}$ MAT2A was down-regulated at gene expression but up-regulated at protein expression in FCA as compared to SCA; X; molecules involved in cell adhesion.

Several proteins belonging to collagen/cell adhesion/extracellular matrix (ECM) components were identified among the 38 molecules differentially expressed at both mRNA and protein level (Table 1). In addition, other cell adhesion genes were significantly increased only at mRNA level in FCA (COL1A1, COL4A3, COL4A4, COL20A1, COL28A1, LEPREL1, SERPINF1 and TIMP3) and SCA (COL2A1, COL11A1, SDC2, SPP1, FN1 and VTN) (Supplementary File S1 DEGs_SEQ).

POMC and TBX19 were higher in the FCA group (Table 1). DKK3 was higher in the FCA group. In addition, other canonical WNT signaling activators (LGR5, RSPO3, and FZD5) were also higher expressed only at gene level in this group.

CRABP2, a protein known to potentiate effect of retinoids, was higher in SCA.

MAT2A showed discrepant regulation in FCA—down-regulated at the gene, but up-regulated at the protein level, perhaps explained by the fact that protein expression of this gene is regulated by post-transcriptional regulation [21].

Interestingly, the GNAS gene and protein were higher expressed in FCA, whereas the highest expressed molecule in the SCA group was NTS (neurotensin), a protein described in one study to be present in tumoral corticotroph cells [22].

\subsection{Network Analysis in FCA and SCA}

An interactive network representing the relations between all DEGs in both adenoma subtypes is presented online at https://alexeie.github.io/corticotroph-adenomas/. A simplified version is presented in Figure 3.

Figure 3 presents in a novel manner simultaneously the relationships between all the DEGs in both subgroups of adenomas. As shown, the relations between differentially expressed genes are complex, and drawing clear conclusions on the clinical significance is difficult. We therefore searched for biological processes and cellular components that were overrepresented in the data set using Panther (Supplementary File S1 biological_process and Supplementary File S1 cellular_component). Based on our a priori hypothesis (i.e., FCA and SCA differ with regard to hormone production and secretion and growth potential), we further selected several biological processes and cellular components of relevance to the clinical implications and tumor phenotypes for detailed analyses (Supplementary File S1 GO selected_SEQ) and created new network representations for FCA and SCA (Figure 4A,B). Protein folding in endoplasmic reticulum, regulation of transmembrane transport, regulation of cell migration, regulation of cell morphogenesis and differentiation, regulation of cell 
population proliferation, regulation of exocytosis, regulation of secretion and cell-cell adhesion were among the selected biological processed. With regard to the cellular component, the processes of importance for secretory cells (e.g., extracellular exosome, melanosome, endoplasmic reticulum lumen, chromaffin granule, cytoplasmic vesicle membrane and endocytic vesicle lumen) or cell adhesion/junction were selected (Supplementary File S1 GO selected_SEQ).

Overrepresentation analyses showed that the FCA and SCA cohort both expressed genes related to biological processes that were expected from secretory endocrine cells (Supplementary File S1 biological_process_SEQ and cellular_component_SEQ). However, the expressed patterns of interactions were not identical. The SCA group expressed functional relations to protein and vesicle processing and to secretory vesicles, but the genes expressed bore few interactions between them. The FCA, however, expressed the same category of genes with a high degree of interactions.

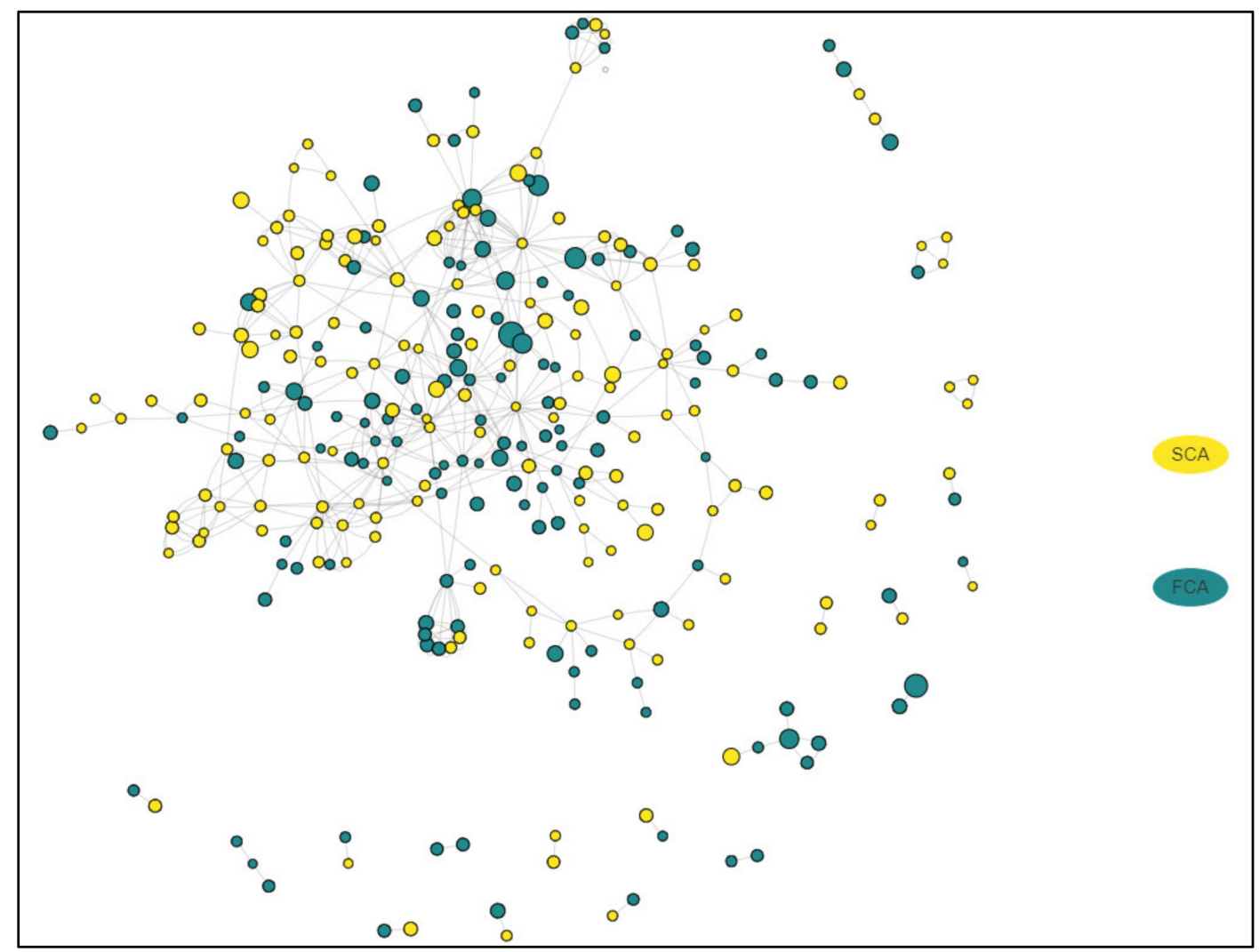

Figure 3. Interactive network representing the relations between all DEGs in functioning (FCA) and silent (SCA) corticotroph adenomas. The figure shows a representation of the complexity of the results and the interactions that are present. An interactive version of this figure is presented at https://alexeie.github.io/corticotroph-adenomas/. Detailed information on all the key interactions in the dataset, including the involved genes and the known relationships between them, can be accessed via the link. Genes higher expressed in FCA group are green; genes higher expressed in SCA are yellow. The size of the round circles is proportional to the log2 fold change.

Among the clusters of interactions overexpressed in FCA, one cluster related to hormone activity and endoplasmic reticulum protein processing and one cluster containing collagen/extra cellular matrix proteins were present (Figure 4A). 

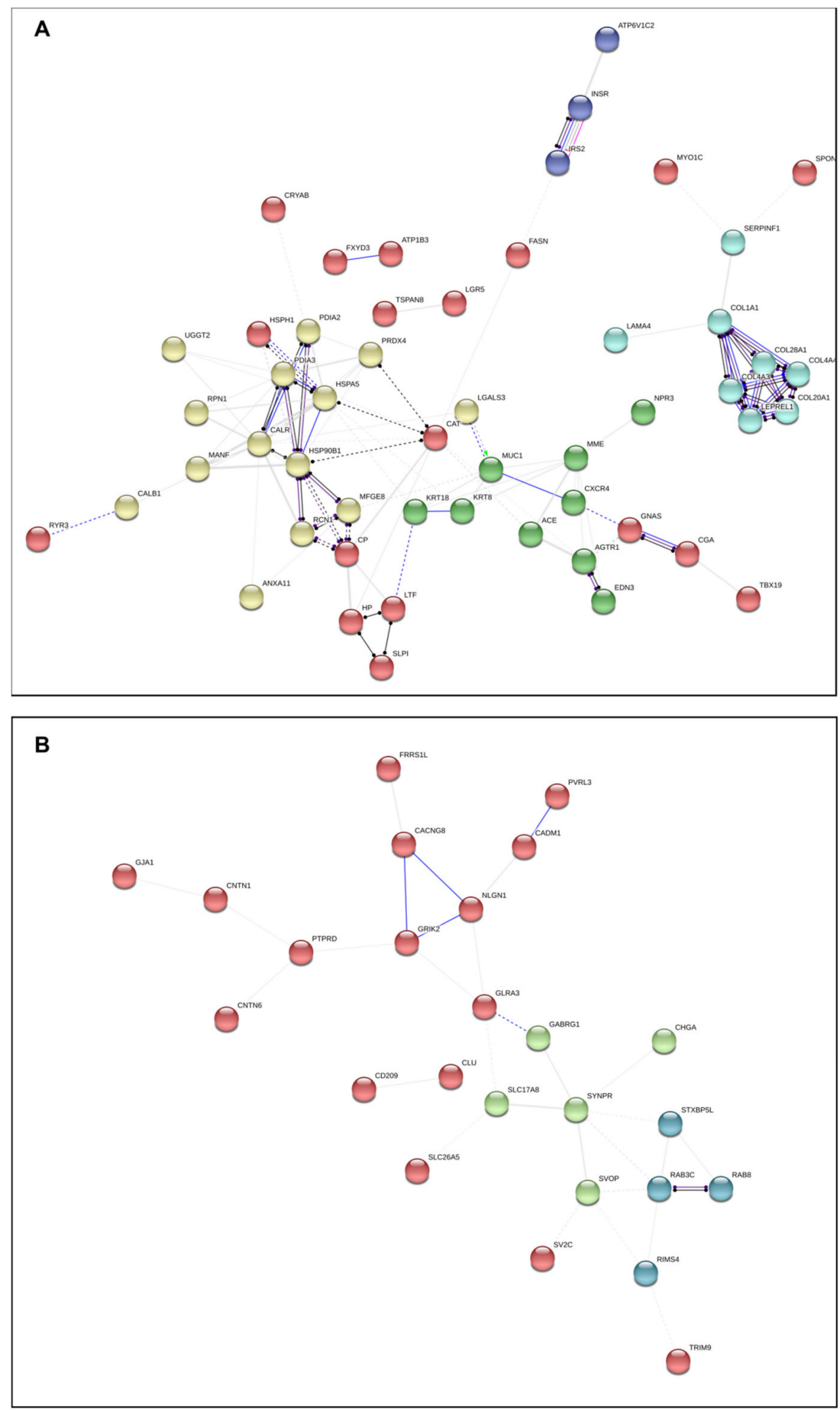

Figure 4. Network analysis presenting DEG interactions in functioning (FCA) (A) and silent (SCA) (B) corticotroph adenomas based on selected distinct biological processes and cellular components overrepresented in FCA and SCA. GO processes representative of the pituitary tumor phenotype or involved in hormone production/secretion and tumor growth were selected to be presented in the figure. For a comprehensive list of all the significant processes in the overrepresentation test and the selected ones, please see Supplementary File S1 (biological_process_SEQ, cellular_component_SEQ, GO selected_SEQ and GO matches_SEQ) and the online figure for FCA at https://version-11-0.string$\mathrm{db}$.org/cgi/network.pl?networkId=6sMwLjjOC4ua and for SCA at https://version-11-0.string-db.org/ cgi/network.pl?networkId=pdN7O6hmQ5G3. The color of the circles indicates the result of a K-means algorithm for identifying clusters of genes according to their interaction partners. 
Among the genes related to hormone activity and endoplasmic reticulum protein processing, FCA showed up-regulation of genes involved in ribosome anchor (RRBP1), glycosylation and folding processes (RPN1, CALR, PDIA3, and UGGT2), protein recognition by luminal chaperones (HSPA5), and ER-associated degradation (HSPH1 and CRYAB). The only gene to be up-regulated in SCA was EIF2AK2, a protein known to phosphorylate translation initiation factor EIF2S1, which, in turn, inhibits protein synthesis. The difference with regard to endoplasmic reticulum protein processing genes was preserved with the exception of EIF2S1 when testing by RT-PCT in a larger cohort of cortiotroph adenomas [23] (Figure S2).

The ECM protein cluster up-regulated in FCA covered several collagen genes in addition to LAMA4, SERPINF1 and SPON2 (Figure 4A and Supplementary File S1 GO matches FCA_SEQ). The particular ECM expression profiles in FCA may be related to their "growth restriction" or even contribute to their active hormonal production.

CXCR4, a cancer stem cell marker in several tumors, inclusively in corticotroph adenomas [24], was higher expressed in FCA. However, Gene Ontology (GO)biological processes analysis (Supplementary File S1 biological_process_SEQ) did not identify the stem cells marks category as one of the differentially expressed between FCA and SCA.

SCA expressed few clusters of biological activities (4 B,). However, a cluster of genes involved in vesicular transport/trafficking (STXBR5L, RAB3C, RAB8B and RIMS4) and another containing genes involved in cell-to-cell interaction (CACNG8, GRIK2, NLGN1, CADM1, and PVRL3) were present. Furthermore, few genes involved in NOTCH signaling (SGK1, CNTN1, and CNTN6) were also identified. SV2C, a protein coding gene which positively regulates vesicle fusion by maintaining the readily releasable pool of secretory vesicles [25], was also higher expressed in SCA.

The somatostatin receptor (SSR) status of different subgroups of adenomas is important, not the least with regard to the use of available medical treatments. There was no statistical difference in SSRs and dopamine receptor type 2 (DRD2) gene expression between functioning and silent corticotroph adenomas (Figure S3). SSR5 and SSR4 were not expressed in the SCA group.

The proteomics analysis identified fewer proteins compared to the number of genes identified by RNA-seq, therefore, the data are less abundant (Figure 5A,B and Supplementary File S1 GO matches FCA_MS2 and GO matches SCA_MS2). We performed network analysis by including all the DEPs.

Several evident protein clusters were identified in the FCA group (Figure 5A). One of them is composed of proteins known to be related to POMC, involving TBX19, PCSK1, GNAS, GFAP, and GALA. Other clusters were related to the extra cellular matrix (GPC1, DCN, COL15A1), neovascularization (VGF, TIPM2, QSOX1), calcium signaling (CACNA2D2, CAMk2B, CAMK2D), and glycolysis (PFKP, PFKFB2, IDH2). In addition, two key regulators of transforming growth factor beta, LTBP3 (also at gene level) and LTBP1, were also present.

Fewer protein clusters were identified in the SCA group (Figure 5B). Of note is the protein expression of PCSK1N, an inhibitor of PCSK1 in addition to two proteins involved in secretory granules (CHGB, SCG3) that were higher in SCA. Interestingly, several proteins known for their functions in the spliceosome were also present (SNRPE, SNRPG and CELF3). SSRs and DRD2 were not identified in the proteomics data set. 

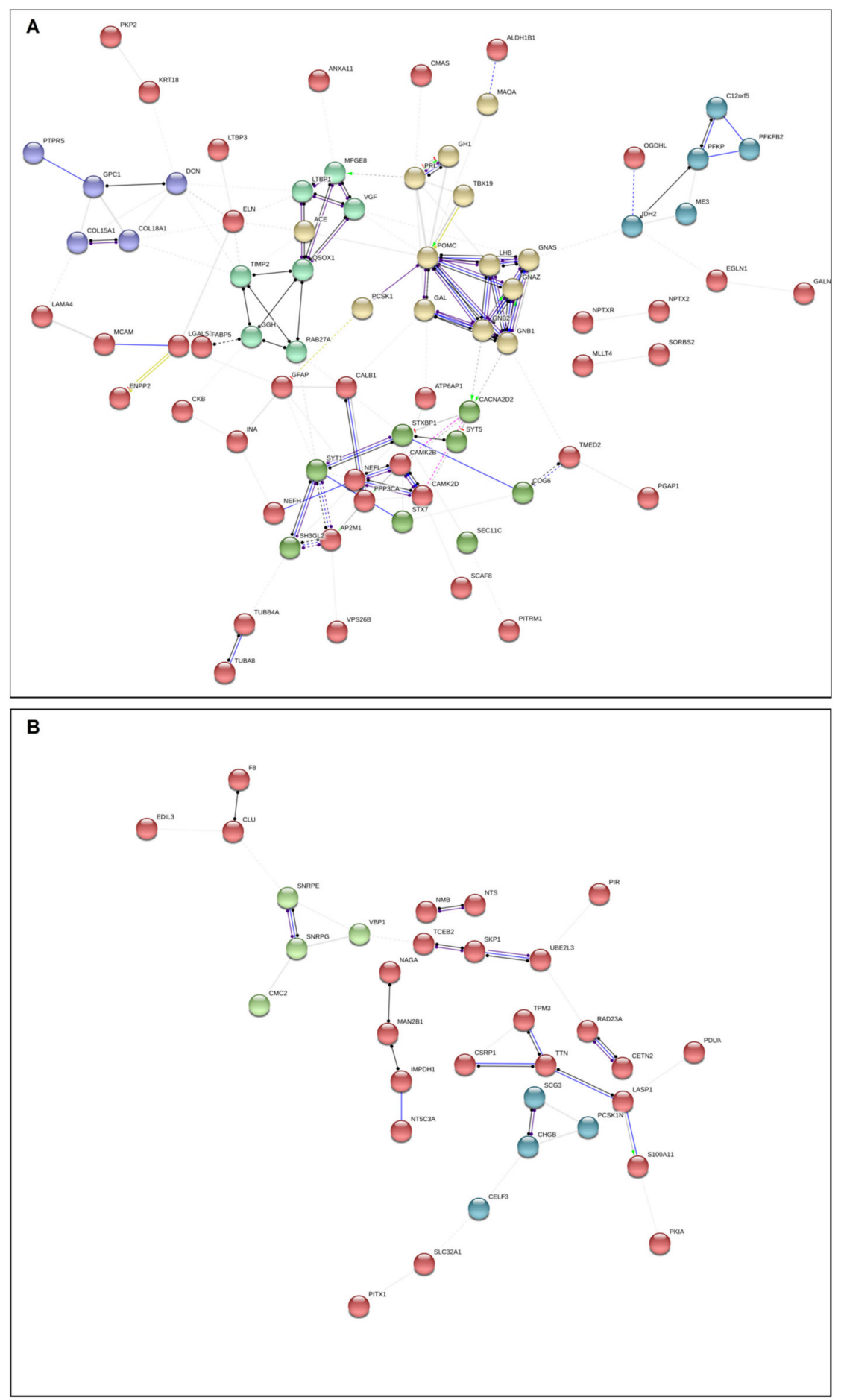

Figure 5. Network analysis presenting all DEP interactions in functioning (FCA) (A) and silent (SCA) (B) corticotroph adenomas. See Supplementary File S1 GO_matches_MS2 and online figures for FCA https://version-11-0.string-db.org/cgi/network.pl?networkId=nBtGbCu86iDj and for SCA https://version11-0.string-db.org/cgi/network.pl?networkId=eC3B7NayyvdC for more detailed information. The color of the circles indicates the result of a K-means algorithm for identifying clusters of genes according to their interaction partners.

\section{Discussion}

We investigated, for the first time, the differences between functioning and silent corticotroph adenomas by performing RNA-seq and quantitative label-free mass spectrometry-based proteomics 
and analyzing network and pathway overexpression. The aim was to identify, first and foremost, the differences with regard to hormone production and secretion, as well as markers of growth and aggressive tumor behavior. The hierarchical clustering revealed two distinct groups in accordance with clinical and histological classification in the transcriptomic study, whereas in the proteomic study, there were four out of 12 silent tumors dispersed within the functioning group. Data visualization showed up-regulation of several genes involved in the protein processing in the endoplasmic reticulum (ER)-pathway in the FCA group. suggesting that an increased protein processing activity may lead to functioning corticotroph adenomas and raising the possibility for identification of a medical treatable target. Moreover, several molecules involved in cell adhesion were differentially regulated between FCA and SCA, indicating a different growth and aggressive potential. As expected, corticotroph cell markers were lower in SCA, and genes and proteins related to biological processes expected in secretory endocrine cells (e.g., vesicle-mediated transport and secretion) were present in both groups.

We present, in a large cohort of corticotroph adenoma, that gene expression of known corticotroph cell markers, POMC, TBX19, and PSCK1 was higher in the functioning group, in accordance with previous reports [26]. A strong association between POMC and TBX19 and PCSK1 expression was found in FCA but not in the SCA group. It is well known that TBX19 controls corticotroph cell identity and terminal differentiation, and inactivation of the TBX19 gene results in loss of POMC expression in corticotrophs [27], so the strong association between POMC and TBX19 was to be expected. Lower POMC and TBX19 expression in SCA supports the hypothesis that the presence of less differentiated cells in SCA is one of the mechanisms to explain diminished hormonal production and secretion. PCSK1 is involved in the initial cleaving of POMC in the anterior pituitary, the first step in acquiring a functional ACTH molecule [19]. Diminished expression of this enzyme in the SCA group, as presented in this study, may contribute to an impaired ACTH production in these tumors. Moreover, we demonstrate that protein level PCSK1N, a well described inhibitor of PCSK1-mediated processing of POMC [28], was significantly increased in SCA, suggesting an additional mechanism responsible for the impaired POMC processing in the silent adenomas. Of notice, a wide biological variability between the different patients was observed with regard to PCSK1 and PCSK2 genes and protein levels, potentially leading to a type-two error. In this sense, the omics studies showed that PCSK1 was significantly increased only at the protein expression level, whereas PCSK2 was significantly decreased only at the gene expression level in FCS.

Clustering of data revealed two distinct groups in the transcriptomic study in accordance with the tumors' clinical phenotype. However, the proteomic study showed more variation with some silent tumors aggregating closer to the functioning counterparts. A lower number of identified proteins compared to the number of genes together with a greater degree of heterogeneity within the SCA may explain the more diffused delimitation observed at the protein level. Indeed, the network analyses also revealed fewer gene/protein clusters within the SCA group, reflecting a potential continuum of functionality, and therefore a broader variability, as previously suggested [5].

The presentation of the transcriptomics data as in Figure 3 is novel and original due to the simultaneously presentation of DEGs presented in both FCA and SCA, and added quantitative information (i.e., $\log 2$ fold change) in the visualization. In all the hitherto available visualization programs, the users have to manually separate up- and down-regulated genes and process them in separate analyses. Thereby, any result is only a partial representation of the underlying biological changes. In addition these figures ignore any underlying quantitative information [29].

Pathway enrichment analyses identified protein processing in the ER signaling pathway as being differentially regulated. The FCA group expressed up-regulation of several genes involved in ER protein folding, suggesting that they pose a higher processing activity compared to their silent counterparts. Indeed, a recent transcriptomic study identified that one of the main characteristics of the expression profile of corticotroph adenomas, per se, was overexpression of protein-targeting to the ER network [30]. Furthermore, it has been shown that unfolded/misfolded proteins accumulated due to the malfunctioning of the processing capacity in the ER leads to global translational repression 
in hypothalamic neurons and within the pituitary [31,32]. Our data suggest that SCA present a diminished ability for ER protein processing, and this may contribute to a decreased POMC gene and protein expression and therefore provide an explanation for their silence.

Another major, innovative finding of our study is the remarkable distinct ECM proteins and cell adhesion molecule profiles presented by the different adenoma types. It is obvious that the anterior pituitary gland comprises a multitude of cell types in addition to hormone specialized cells (e.g., folliculostellate cells, pituitary stem cells, and endothelial and connective tissue cells) [33,34]. All these cells may express and produce ECM components and cell adhesion molecules, although the contribution of each cell subtype is difficult to assess. Few studies have investigated different cell adhesion molecules and found them to be differentially expressed in SCA [35,36]. In our study, FCA presented up-regulation of several collagen genes, although SCA also overexpressed some other collagens. The differences were also evident at the protein level. The alterations seen between the two groups may be attributed to different cell populations or different expression of these molecules by similar cell types. Performing single-cell RNA-seq in FCA and SCA may give an answer to this question. In addition, further mechanistic studies to assess the role of these molecules will be needed to identify their importance in aggressiveness in SCA or perhaps growth restriction in FCA, or even in the regulation of hormone production as previously suggested [37].

The ECM plays a critical role in tumorigenesis and invasiveness/aggressiveness in several cancers, being a bridge between cell differentiation and proliferation, angiogenesis, and cell motility. The epithelial-mesenchymal transition process (EMT) has previously been studied in several subtypes of pituitary tumors and found to be of importance for both hormone production and aggressiveness [38-41]. Interestingly, in a recent multi-omics study, the silent corticotroph tumors presented low EMT, whereas USP8-wild-type functioning tumors showed and increased EMT, somehow challenging the classical imagistic phenotype of SCA as an aggressive tumor [42].

Our data showed that CRABP2, a member of the retinoic acid binding protein family, which transports retinoic acid to the nucleus and regulates its access to the nuclear retinoic acid receptors [43], was higher in the SCA group. Retinoic acids inhibit the transcription of POMC in corticotroph tumor cells, making the drug a candidate for treatment of Cushing disease [44,45]. Thus, the increased retinoic acid signaling in SCA may explain their reduced POMC levels and contribute to the silence.

Activation of calcium channels and intracellular calcium levels is regulated by $\mathrm{CRH}$ via $\mathrm{CRH}$ receptor 1 in the corticotrophs, leading to the release of secretory ACTH-containing vesicles [46,47]. Several calcium channel genes and proteins were up-regulated differentially in FCA and SCA. Functional characterization studies are needed to better understand their role on hormone regulation in corticotroph tumors.

GNAS genes and proteins, functioning as transducers in numerous signaling pathways controlled by $G$ protein-coupled receptors, and known to mutate in several somatotroph adenomas [48], were higher expressed in FCA. Their importance in regard to hormone production in corticotroph adenomas, however, remains to be established.

LGALS3, a carbohydrate binding protein involved in apoptosis, innate immunity, cell adhesion and T-cell regulation, has been proposed as a molecular marker to differentiate between FCA and SCA $[13,49,50]$. Indeed, we found that LGALS3 was higher at the gene and protein level in FCA, and network analysis further identified MUC1, a protein involved in cell adhesion [51], as one of the interacting genes. Although activation of MUC1-mediated signaling in an autocrine/paracrine manner caused by ligation of LGALS3 promotes uncontrolled tumor cell malignancy [52], no role on hormone production/secretion has been described yet for this protein.

Galanine (GAL) was the protein with the highest fold of change in favor of FCA. However, the gene expression data did not display significantly different expression due to heterogeneous expression in SCA with some tumors expressing relatively high levels. Our data and previous reports suggest that GAL can be considered as a marker of corticotroph cell origin, although one cannot explain 
the large difference between the FCA and SCA groups, as no role in hormone production has been described $[53,54]$.

In FCA, both GH and PRL showed higher expression at the gene and protein level, although the levels varied greatly between the samples. This was most probably due to normal pituitary tissue contamination of the small functioning corticotroph tumors, as GH is one of the highest expressed genes in the normal pituitary $[30,34,55,56]$. However, when the data were analyzed after the FCA samples with high expression GH and PRL were removed, the results and their interpretation were similar.

There was no clear evidence of the presence of consistent differences in the activation of classical developmental signaling pathways (i.e., TGF-beta signaling, WNT signaling, Hippo signaling, Notch signaling) between the groups. However, we identified few markers to be significantly different. These signaling pathways have often several layers of regulation, and activation often implies phosphorylation of key proteins, so one should be cautious when interpreting gene data alone.

DKK3, found to be increased at the gene and protein level in FCA, is considered to be a tumor suppressor involved in several cancers [57] and, most interestingly, described as required for maintaining the integrity of secretory vesicles in mouse adrenal glands [58]. Further studies with regard to this marker might reveal its role in modulating both hormone production and tumor growth restriction in corticotroph adenomas.

This study has some limitations. Pre-operative MR pictures were not available for all patients, thus limiting the information of invasiveness of the tumors. However, the main aim of the study was to explore the differences between functioning and non-functioning corticotroph adenomas with regard to their transcriptome and proteome. Thus, invasiveness was not considered as one of our criteria. As for other studies on SCA [8], preclinical evaluation of cortisol rhythm was not available for this group. All the SCA patients were clinically evaluated pre-operatively at our tertiary referral center, and no clinical signs of cortisol hypersecretion were documented. Of note, and a strength of this study, is that the IHC staining for TBX19 and ACTH was performed in a research setting in one run for all tumors, using a specific antibody to detect transcription factor TBX19 [59]. Lastly, the mutational status of USP8 was unknown. A recent pangenomic classification of pituitary neuroendocrine tumors divided the corticotroph functioning tumors into two classes: the USP8-mutated type with overt secretion, and the USP8-wild-type with increased invasiveness and increased epithelial-mesenchymal transition [42]. Our FCA group contains potentially a blending of USP8-wild-type and mutated tumors, potentially diminishing the power of identifying differences. Moreover, the transcriptomics analysis revealed that all the FCA grouped together, with no obvious separation between them.

\section{Material and Methods}

\subsection{Sample Selection}

The samples included in this study were selected from a larger cohort of pituitary adenomas $[41,60,61]$ (FCA, $n=48$, and NFPA, $n=255$ ) based on positive IHC staining for ACTH and TBX19, expression of POMC and TBX19 by real-time quantitative PCR (RT-qPCR) and sufficient RNA quality. RT-qPCR for POMC, TBX19 and PCSK1 was performed in an extended cohort of adenomas (FCA $n=27$, SCA $n=10$ ) in one run. RNA-seq was performed on $6 \mathrm{FCA}$ and $6 \mathrm{SCA}$, whereas proteomics was performed on 12 FCA and 12 SCA (Figure 6). The amount of protein was insufficient in two FCA, so only four FCA and six SCA were used for both RNA-seq and proteomics studies.

The clinical characteristics of patients included in the RNA-seq and proteomics studies are presented in Table S1. The patients diagnosed with FCA had signs and symptoms of endogenous hypercortisolism, and the clinical diagnosis of Cushing's disease was confirmed in all patients. SCA was diagnosed because of tumor symptoms such as visual field defect, headache and/or hormone deficit symptoms (i.e., amenorrhea) and did not present signs and symptoms of endogenous hypercortisolism. 


\begin{tabular}{|c|c|c|c|}
\hline \multicolumn{2}{|c|}{$\begin{array}{l}\text { RNA sequencing } \\
\text { Illumina High seq. } 4000\end{array}$} & \multicolumn{2}{|c|}{$\begin{array}{c}\text { Proteomics } \\
\text { Quantitative label-free proteomics }\end{array}$} \\
\hline \multicolumn{4}{|c|}{ Samples included in analysis } \\
\hline 6 FCA & 6 SCA & 12 FCA & 12 SCA \\
\hline \multicolumn{4}{|c|}{4 FCA + 6 SCA in both } \\
\hline \multicolumn{2}{|c|}{$\begin{array}{l}631 \text { Differentially Expressed Genes } \\
\text { (DEGs) Fold change }>1.8 \text { and } q<0.05\end{array}$} & \multicolumn{2}{|c|}{$\begin{array}{l}170 \text { Differentially Expressed Proteins } \\
\text { (DEPs) Fold change }>1.6 \text { and } p<0.05\end{array}$} \\
\hline $\begin{array}{l}\text { FCA } 286 \text { genes } \\
\text { up-regulated }\end{array}$ & $\begin{array}{l}\text { SCA } 345 \text { genes } \\
\text { up-regulated }\end{array}$ & $\begin{array}{l}\text { FCA } 102 \text { proteins } \\
\text { up-regulated }\end{array}$ & $\begin{array}{l}\text { SCA } 68 \text { proteins } \\
\text { up-regulated }\end{array}$ \\
\hline \multicolumn{4}{|c|}{38 molecules common in both } \\
\hline
\end{tabular}

Figure 6. Study design.

Written informed consent was obtained from all patients. The study was approved by the regional ethics committee (REK no: 2014/1680, REK no: 2014/635 and REK no: 2020/22301) and hospital authority. Data were analyzed using IBM SPSS statistics version 26.0 (SPSS, Chicago, IL, USA).

\subsection{RNA Isolation and Reverse Transcription}

Tissue was homogenized in Trizol (Invitrogen, Carlsbad, CA, USA), and RNA was purified using QIAGEN miRNeasy Mini Kit (Qiagen, Valencia, CA, USA), according to the manufacturer's instructions, including the step for removal of genomic DNA. RNA integrity was determined using the Agilent 2100 Bioanalyzer (Agilent Technologies, Santa Clara, CA, USA), and concentrations were measured by optical density OD readings on a Nanodrop ND-1000 Spectrophotometer (Nanodrop Technologies, Wilmington, DE). All RNA integrity numbers (RIN) were above 7, indicating a high RNA quality [62].

Reverse transcription was performed using a High Capacity cDNA Reverse Transcription Kit (Applied Biosystems, Foster City, CA, USA) in a Labnet MultiGene Gradient Thermal Cycler (Labnet International Inc, Edison, NJ, USA) according to the manufacturer's protocol using a total of $1 \mu \mathrm{g}$ RNA. After the reaction, the cDNA was diluted to a ratio of 1:10.

\section{3. $R T-q P C R$}

RT-qPCR was performed in the ABI 7900 (Applied Biosystems, Foster City, CA, USA). Applied Biosystems ${ }^{\mathrm{TM}}$ Power $^{\mathrm{TM}}$ SYBR $^{\mathrm{TM}}$ Green Master Mix and samples were dispensed in the corresponding wells by an automated pipetting system (epMotion ${ }^{\circledR} 5070 \mathrm{CB}$, Hamburg, Germany).

Primer pairs were found either in the literature or in the primer bank (Harward medical school C., 2006) and are presented in Supplementary File S1 primers. All primers were tested for specificity using BLAST analysis (NCBI). To avoid false positive amplification due to DNA contamination, the genomic DNA sequence (downloaded from Ensemble Data Base www.ensembl.org), was used to check exon-intron borders by matching the primers to their location. The amplification efficiency and correlation coefficients for these primers (Sigma Aldrich, St. Louis, MO, US) were obtained from the slope of the standard curves. All RT-qPCR experiments were in accordance with the Minimum Information for Publication of Quantitative Real-Time PCR Experiments (MIQE) guidelines. Data were adjusted to geometrical mean of two housekeeping genes (GAPDH and ALAS1) as previously validated [63].

\subsection{RNA-Seq}

RNA-seq was performed using $2 \mu \mathrm{g}$ RNA for each sample $(n=12)$ at the Norwegian Sequencing Centre, Oslo, Norway. Twelve RNA-seq libraries with unique indexes were prepared using TruSeq stranded mRNA library prep kit (Illumina, San Diego, CA, USA) by following the manufacturer's instructions. Two batches of six libraries were pooled together, and $150 \mathrm{nt}$ paired-end sequencing was performed on one lane of HiSeq 4000 (Illumina) for each batch. RTA v1.18.66.3 was used for base 
calling and was further processed using bc2fastq v2.17.1.14 to demultiplex and generate fastq data based on the indexes used during library preparation.

\subsection{Pre-Processing and Cleanup}

Low-quality reads and adaptors were removed using Trimmomatic v0.33 [64] with recommended parameters. BBMap v34.56 (http://sourceforge.net/projects/bbmap) was used to remove reads aligning to PhiX (RefSeq: NC_001422.1), which was added as a spike-in during sequencing.

\subsection{Transcriptome Alignment}

Cleaned data were aligned against the Human ensemble GRCh38 (p10, release 90) genome and the transcriptome using Tophat2 v2.0.13 [65], using '-library-type fr-firststrand -no-mixed -no-novel-juncs -transcriptome-index' as parameters. Library size was estimated using the picard v1.112 (http://broadinstitute.github.io/picard/) CollectInsertSizeMetrics tool after aligning the first one million reads using bowtie v2.2.3 [66] to human ensemble GRCh38 cDNA sequences, and the output was also provided as parameters for tophat2 alignment. Cuffdiff v2.2.1 [67] pipeline was used to calculate the differential expression of the known genes described in ensemble General Feature Format (GTF) and CummeRbund v2.14 [68]. R package was used to visualize expression data, and custom scripts were used to create tables and graphs. Hierarchical clustering was performed using Pearson correlation with complete linkage in TM4 MeV (http://mev.tm4.org/).

\subsection{Quantitative Label-Free Mass Spectrometry-Based Proteomic Analysis}

Tissue samples stored in TRIzol ${ }^{\mathrm{TM}}$ reagent (Thermo Fisher Scientific, Invitrogen, Carlsbad, CA, USA) were homogenized according to the manufacturer's protocol. RNA supernatant was removed, ethanol was added for DNA precipitation, and the resulting protein pellet was utilized for proteomic analysis. The proteins were dissolved in $8 \mathrm{M}$ urea in $50 \mathrm{mM} \mathrm{NH} \mathrm{HCO}_{3}$, reduced and alkylated, and digested into peptides with trypsin (Promega, Madison, Wisconsin, USA). The resulting peptides were desalted and concentrated before mass spectrometry (MS) by the STAGE-TIP method using a C18 resin disk (3M Empore, St. Paul, MN, USA). Each peptide mixture was analyzed by a nEASY-LC coupled to a QExactive Plus (ThermoElectron, Bremen, Germany) with an EASY Spray PepMap ${ }^{\circledR}$ RSLC column (C18, Thermo Fisher Scientific, Carlsbad, CA, USA).

The resulting MS raw files were submitted to the MaxQuant software version 1.6.1.0 for protein identification and label-free quantification. Carbamidomethyl (C) was set as a fixed modification, and acetyl (protein $\mathrm{N}$-term), carbamyl ( $\mathrm{N}$-term) and oxidation $(\mathrm{M})$ were set as variable modifications. A first search peptide tolerance of $20 \mathrm{ppm}$ and a main search error $4.5 \mathrm{ppm}$ were used. Trypsin without the proline restriction enzyme option was used, with two miscleavages allowed. The minimal unique + razor peptide number was set to 1 , and the allowed false discovery rate (FDR) was $0.01(1 \%)$ for peptide and protein identification. Label-free quantitation was employed with default settings. The Uniprot database with "human" entries (September 2018) was used for the database searches.

Known contaminants as provided by MaxQuant and identified in the samples were excluded from further analysis. Perseus version 1.6.1.3 was used for further analysis of MaxQuant data: label-free quantitation (LFQ) intensity values were $\log 10$ transformed, a minimum of $50 \%$ valid values in at least one group was required, and missing values were imputed from the low end of normal distribution. Student's T-test between the groups $(p<0.05)$ was performed to find the significant DEPs.

\subsection{Pathways}

For comparison purposes, protein level values were changed from $\log 10$ to $\log 2$ in order to facilitate comparison with RNA-seq data. Proteins with a $\log 2$ fold change higher than 1 (i.e., a fold change of 2) and genes with a $\log 2$ fold change higher than 0.92 (i.e., a fold of change 1.8) were considered for network and pathway analysis. 
After a Student's $T$-test was performed, the resulting set of differentially expressed genes (DEGs)/differentially expressed proteins (DEPs) were utilized in an overrepresentation test in Panther-db with Fischer's exact test controlling for false positives by Benjamini Hochberg's false discovery rate (FDR). For DEGs, the complex list of pathways was also further curated by eliminating pathways that were not considered informative to the pituitary tumor phenotype or involved in hormone production/secretion and tumor growth. DEPs were presented in the network without any selection due to the fact that the proteomic data included only 170 DEPs and the figures were less complex.

The interactions between the detected gene products' and proteins' remaining biological pathways were investigated by plotting the corresponding genes' protein interactions in the String-db web interface with medium confidence while hiding disconnected nodes.

To assess if the DEPs displayed any network connectivity (and thus pointing to biological pathways of interest), the online String database and Panther database were employed to visualize and assess the presence of protein interactions $[69,70]$.

Overrepresentation analysis was performed with Panther-db using Homo sapiens as a reference genome. Two-log fold enrichment of the overrepresentation test ranged from 1.36 to 4.77 and from 0.96 to 6.64 for the selected genes and proteins, respectively.

\subsection{Heatmap and $P C A$}

A heatmap was generated for transcriptomic and proteomic data by use of R packages Plotly and Heatmaply [71,72]. The heatmap displays significantly expressed transcripts and proteins on a Z-scored color scale that indicates the number of standard deviations that each variable deviates from the variable mean, and the branches are colored according to which second-level branch they belong to.

Principal component analysis (PCA) was performed on both data sets, on complete data without any selection. PCA plots for RNA-seq data and proteomic data are represented with $41 \%$ and $48 \%$ of total variance, respectively.

\section{Conclusions}

Distinct clinical aspects of FCA and SCA may be explained by their different repertoires of activated signaling pathways, namely, promoting growth in SCA and protein processing in FCA and their specific patterns of cell adhesion molecules. Further in vitro functional studies should be performed in order to identify possible medical targets and to properly understand the involved mechanisms.

Supplementary Materials: The following are available online at http://www.mdpi.com/2072-6694/12/10/2980/s1, Supplementary File S1: Tanscriptomic and proteomic data, Table S1: Clinical characteristics of patients with functioning (FCA) and silent (SCA) corticotroph pituitary adenomas title, Figure S1: Coronal MRI pictures of a functioning FCA (A) and a silent SCA (B) pituitary corticotroph adenoma, Figure S2: Increased protein processing activity of endoplasmic reticulum in functioning pituitary corticotroph adenoma (FCA), Figure S3: Gene expression of somatostatin receptors (SSRs) 1-5 and dopamine receptor type 2 (DRD2) in functioning (FCA) and silent (SCA) corticotroph pituitary adenomas.

Author Contributions: Each author has made substantial contributions to the conception or design of the work, or the acquisition, analysis, or interpretation of data for the work. The authors have drafted the work or substantively revised it, and they have approved the submitted version and agree to be personally accountable for their own contributions and for ensuring that questions related to the accuracy or integrity of any part of the work, even those in which they were not personally involved, are appropriately investigated, resolved, and documented in the literature. All authors have read and agree to the published version of the manuscript. Conceptualization, K.R.N., J.B., and NCO; methodology A.K.E., K.R.N., A.Y.M.S., T.A.N., and N.C.O.; software, A.K.E., and A.Y.M.S; validation, K.R.N., TL, N.C.O..; formal analysis, A.K.E., K.R.N., A.Y.M.S., T.A.N., and N.C.O.; resources K.R.N., K.A.B.Ø., T.L., J.P.B., J.B. and N.C.O.; data curation, A.K.E., A.Y.M.S., T.A.N.; writing-original draft preparation, K.R.N., and N.C.O.; writing-review and editing, A.K.E., K.R.N, A.Y.M.S., T.A.N., K.A.B.Ø., T.L., J.P.B, J.B., and N.C.O; visualization, A.K.E.; supervision, J.B., and N.C.O.; project administration, N.C.O.; funding acquisition, J.B.

Funding: This research received no external funding.

Acknowledgments: KABØ and NCO received scholarships provided by Southern and Eastern Norway Regional Health Authority (Helse Sør-Øst).

Conflicts of Interest: The authors declare no potential conflicts of interest. 


\section{References}

1. Agustsson, T.T.; Baldvinsdottir, T.; Jonasson, J.G.; Ólafsdóttir, E.; Steinthorsdottir, V.; Sigurdsson, G.; Thorsson, A.V.; Carroll, P.V.; Korbonits, M.; Benediktsson, R. The epidemiology of pituitary adenomas in Iceland, 1955-2012: A nationwide population-based study. Eur. J. Endocrinol. 2015, 173, 655-664. [CrossRef] [PubMed]

2. Tjörnstrand, A.; Gunnarsson, K.; Evert, M.; Holmberg, E.; Ragnarsson, O.; Rosén, T.; Nyström, H.F. The incidence rate of pituitary adenomas in western Sweden for the period 2001-2011. Eur. J. Endocrinol. 2014, 171, 519-526. [CrossRef]

3. Cooper, O.; Melmed, S. Subclinical hyperfunctioning pituitary adenomas: The silent tumors. Best Pr. Res. Clin. Endocrinol. Metab. 2012, 26, 447-460. [CrossRef]

4. Ntali, G.; Capatina, C.; Fazal-Sanderson, V.; Byrne, J.V.; Cudlip, S.; Grossman, A.; Wass, J.A.; Karavitaki, N. Mortality in patients with non-functioning pituitary adenoma is increased: Systematic analysis of 546 cases with long follow-up. Eur. J. Endocrinol. 2016, 174, 137-145. [CrossRef]

5. Drummond, J.; Roncaroli, F.; Grossman, A.B.; Korbonits, M. Clinical and Pathological Aspects of Silent Pituitary Adenomas. J. Clin. Endocrinol. Metab. 2018, 104, 2473-2489. [CrossRef] [PubMed]

6. Karavitaki, N. Prevalence and incidence of pituitary adenomas. Ann. d'Endocrinologie 2012, 73, 79-80. [CrossRef] [PubMed]

7. Raappana, A.; Koivukangas, J.; Ebeling, T.; Pirilä, T. Incidence of Pituitary Adenomas in Northern Finland in 1992-2007. J. Clin. Endocrinol. Metab. 2010, 95, 4268-4275. [CrossRef]

8. Cohen-Inbar, O.; Xu, Z.; Lee, C.-C.; Wu, C.-C.; Chytka, T.; Silva, D.; Sharma, M.; Radwan, H.; Grills, I.S.; Nguyen, B.; et al. Prognostic significance of corticotroph staining in radiosurgery for non-functioning pituitary adenomas: A multicenter study. J. Neuro-Oncology 2017, 135, 67-74. [CrossRef]

9. Cooper, O.; Ben-Shlomo, A.; Bonert, V.; Bannykh, S.; Mirocha, J.; Melmed, S. Silent Corticogonadotroph Adenomas: Clinical and Cellular Characteristics and Long-Term Outcomes. Horm. Cancer 2010, 1, 80-92. [CrossRef]

10. Jahangiri, A.; Wagner, J.R.; Pekmezci, M.; Hiniker, A.; Chang, E.F.; Kunwar, S.; Blevins, L.; Aghi, M.K. A Comprehensive Long-term Retrospective Analysis of Silent Corticotrophic Adenomas vs. Hormone-Negative Adenomas. Neurosurg. 2013, 73, 8-18. [CrossRef]

11. Langlois, F.; Lim, D.S.T.; Yedinak, C.G.; Cetas, I.; McCartney, S.; Cetas, J.; Dogan, A.; Fleseriu, M. Predictors of silent corticotroph adenoma recurrence; a large retrospective single center study and systematic literature review. Pituit. 2017, 21, 32-40. [CrossRef]

12. Pawlikowski, M.; Kunert-Radek, J.; Radek, M. “Silent” corticotropinoma. Neuro Endocrinol. Lett. 2008, 29, 347-350. [PubMed]

13. Raverot, G.; Wierinckx, A.; Jouanneau, E.; Auger, C.; Borson-Chazot, F.; Lachuer, J.; Pugeat, M.; Trouillas, J. Clinical, hormonal and molecular characterization of pituitary ACTH adenomas without (silent corticotroph adenomas) and with Cushing's disease. Eur. J. Endocrinol. 2010, 163, 35-43. [CrossRef] [PubMed]

14. Tateno, T.; Izumiyama, H.; Doi, M.; Yoshimoto, T.; Shichiri, M.; Inoshita, N.; Oyama, K.; Yamada, S.; Hirata, Y. Differential gene expression in ACTH -secreting and non-functioning pituitary tumors. Eur. J. Endocrinol. 2007, 157, 717-724. [CrossRef] [PubMed]

15. Ben-Shlomo, A.; Cooper, O. Silent corticotroph adenomas. Pituit. 2018, 21, 183-193. [CrossRef] [PubMed]

16. Kojima, Y.; Suzuki, S.; Yamamura, K.; Ohhashi, G.; Yamamoto, I. Comparison of ACTH secretion in Cushing's adenoma and clinically silent corticotroph adenoma by cell immunoblot assay. Endocr J. 2002, 49, 285-292. [CrossRef]

17. Tateno, T.; Kato, M.; Tani, Y.; Yoshimoto, T.; Oki, Y.; Hirata, Y. Processing of high-molecular-weight form adrenocorticotropin in human adrenocorticotropin-secreting tumor cell line (DMS-79) after transfection of prohormone convertase 1/3 gene. J. Endocrinol. Investig. 2009, 33, 113-117. [CrossRef] [PubMed]

18. Parvin, R.; Saito-Hakoda, A.; Shimada, H.; Shimizu, K.; Noro, E.; Iwasaki, Y.; Fujiwara, K.; Yokoyama, A.; Sugawara, A. Role of NeuroD1 on the negative regulation of Pomc expression by glucocorticoid. PLoS ONE 2017, 12, e0175435. [CrossRef] [PubMed]

19. Harno, E.; Ramamoorthy, T.G.; Coll, A.P.; White, A. POMC: The Physiological Power of Hormone Processing. Physiol. Rev. 2018, 98, 2381-2430. [CrossRef] [PubMed]

20. Tabuchi, Y.; Kitamura, T.; Fukuhara, A.; Mukai, K.; Onodera, T.; Miyata, Y.; Hamasaki, T.; Oshino, S.; Saitoh, Y.; Morii, E.; et al. Nur77 gene expression levels were involved in different ACTH-secretion autonomy between Cushing's disease and subclinical Cushing's disease. Endocr. J. 2016, 63, 545-554. [CrossRef] [PubMed] 
21. Pendleton, K.E.; Chen, B.; Liu, K.; Hunter, O.V.; Xie, Y.; Tu, B.P.; Conrad, N.K. The U6 snRNA m 6 A Methyltransferase METTL16 Regulates SAM Synthetase Intron Retention. Cell 2017, 169, 824-835.e14. [CrossRef]

22. Reyes, R.; Valladares, F.; Díaz-Flores, L.; Feria, L.; Alonso, R.; Tramu, G.; Bello, A.R.; Reyes, R. Immunohistochemical localization of hormones and peptides in the human pituitary cells in a case of hypercortisolism by ACTH secreting microadenoma. Histol. Histopathol. 2007, 22, 709-717. [PubMed]

23. Olarescu, N.C.; Normann, K.R.; Sundaram, A.Y.; Oystese, K.A.B.; Eieland, A.; Lekva, T.; Bollerslev, J. Pathway enrichment analysis in functioning and silent corticotroph pituitary adenomas reveals mechanisms to explain their distinct clinical behaviour. Endocr. Abstr. 2019, 63 GP154. [CrossRef]

24. Mertens, F.; Gremeaux, L.; Chen, J.; Fu, Q.; Willems, C.; Roose, H.; Govaere, O.; Roskams, T.; Cristina, C.; Becú-Villalobos, D.; et al. Pituitary tumors contain a side population with tumor stem cell-associated characteristics. Endocr. Relat. Cancer 2015, 22, 481-504. [CrossRef]

25. Stout, K.A.; Dunn, A.R.; Hoffman, C.; Miller, G.W. The Synaptic Vesicle Glycoprotein 2: Structure, Function, and Disease Relevance. ACS Chem. Neurosci. 2019, 10, 3927-3938. [CrossRef]

26. García-Martínez, A.; Cano, D.A.; Flores-Martínez, Á.; Gil, J.; Domingo, M.P.; Webb, S.M.; Soto-Moreno, A.; Pico, A.M.; Soto, A. Why don't corticotroph tumors always produce Cushing's disease? Eur. J. Endocrinol. 2019, 181, 351-361. [CrossRef] [PubMed]

27. Pulichino, A.-M.; Vallette-Kasic, S.; Tsai, J.P.-Y.; Couture, C.; Gauthier, Y.; Drouin, J. Tpit determines alternate fates during pituitary cell differentiation. Genes Dev. 2003, 17, 738-747. [CrossRef]

28. Fortenberry, Y.; Hwang, J.-R.; Apletalina, E.V.; Lindberg, I. Functional Characterization of ProSAAS. J. Biol. Chem. 2001, 277, 5175-5186. [CrossRef] [PubMed]

29. Griss, J.; Viteri, G.; Sidiropoulos, K.; Nguyen, V.; Fabregat, A.; Hermjakob, H. ReactomeGSA-Efficient Multi-Omics Comparative Pathway Analysis. Mol. Cell. Proteom. 2020. [CrossRef] [PubMed]

30. Cassarino, M.F.; Ambrogio, A.G.; Cassarino, A.; Terreni, M.R.; Gentilini, D.; Sesta, A.; Cavagnini, F.; Losa, M.; Giraldi, F.P. Gene expression profiling in human corticotroph tumours reveals distinct, neuroendocrine profiles. J. Neuroendocr. 2018, 30, e12628. [CrossRef]

31. Khetchoumian, K.; Balsalobre, A.; Mayran, A.; Christian, H.; Chénard, V.; St-Pierre, J.; Drouin, J. Pituitary cell translation and secretory capacities are enhanced cell autonomously by the transcription factor Creb312. Nat. Commun. 2019, 10, 3960. [CrossRef]

32. Cakir, I.; Nillni, E.A. Endoplasmic Reticulum Stress, the Hypothalamus, and Energy Balance. Trends Endocrinol. Metab. 2019, 30, 163-176. [CrossRef] [PubMed]

33. Fletcher, P.A.; Smiljanic, K.; Prévide, R.M.; Iben, J.R.; Li, T.; Rokic, M.B.; Sherman, A.; Coon, S.L.; Stojilkovic, S.S. Cell Type- and Sex-Dependent Transcriptome Profiles of Rat Anterior Pituitary Cells. Front. Endocrinol. 2019, 10, 623. [CrossRef] [PubMed]

34. Cheung, L.Y.M.; George, A.S.; McGee, S.R.; Daly, A.Z.; Brinkmeier, M.L.; Ellsworth, B.S.; Camper, S.A. Single-Cell RNA Sequencing Reveals Novel Markers of Male Pituitary Stem Cells and Hormone-Producing Cell Types. Endocrinology 2018, 159, 3910-3924. [CrossRef] [PubMed]

35. Mete, O.; Hayhurst, C.; Alahmadi, H.; Monsalves, E.; Gücer, H.; Gentili, F.; Ezzat, S.; Asa, S.L.; Zadeh, G. The Role of Mediators of Cell Invasiveness, Motility, and Migration in the Pathogenesis of Silent Corticotroph Adenomas. Endocr. Pathol. 2013, 24, 191-198. [CrossRef] [PubMed]

36. Di Ieva, A.; Davidson, J.M.; Syro, L.V.; Rotondo, F.; Montoya, J.F.; Horvath, E.; Cusimano, M.D.; Kovacs, K. Crooke's Cell Tumors of the Pituitary. Neurosurg. 2015, 76, 616-622. [CrossRef]

37. Kuchenbauer, F.; Hopfner, U.; Stalla, J.; Arzt, E.; Stalla, G.K.; Paez-Pereda, M. Extracellular matrix components regulate ACTH production and proliferation in corticotroph tumor cells. Mol. Cell. Endocrinol. 2001, 175, 141-148. [CrossRef]

38. Øystese, K.A.; Berg, J.P.; Normann, K.R.; Zucknick, M.; Casar-Borota, O.; Bollerslev, J. The role of E and N-cadherin in the postoperative course of gonadotroph pituitary tumours. Endocr. 2018, 62, 351-360. [CrossRef]

39. Falch, C.M.; Sundaram, A.Y.; Øystese, K.A.; Normann, K.R.; Lekva, T.; Silamikelis, I.; Eieland, A.K.; Anderson, M.; Bollerslev, J.; Olarescu, N.C. Gene expression profiling of fast- and slow-growing non-functioning gonadotroph pituitary adenomas. Eur. J. Endocrinol. 2018, 178, 295-307. [CrossRef]

40. Lekva, T.; Berg, J.P.; Fougner, S.L.; Olstad, O.K.; Ueland, T.; Bollerslev, J. Gene Expression Profiling Identifies ESRP1 as a Potential Regulator of Epithelial Mesenchymal Transition in Somatotroph Adenomas from a Large Cohort of Patients with Acromegaly. J. Clin. Endocrinol. Metab. 2012, 97, E1506-E1514. [CrossRef] 
41. Evang, J.A.; Berg, J.P.; Casar-Borota, O.; Lekva, T.; Kringen, M.K.; Ramm-Pettersen, J.; Bollerslev, J. Reduced levels of E-cadherin correlate with progression of corticotroph pituitary tumours. Clin. Endocrinol. 2011, 75, 811-818. [CrossRef] [PubMed]

42. Neou, M.; Villa, C.; Armignacco, R.; Jouinot, A.; Raffin-Sanson, M.-L.; Septier, A.; Letourneur, F.; Diry, S.; Diedisheim, M.; Izac, B.; et al. Pangenomic Classification of Pituitary Neuroendocrine Tumors. Cancer Cell 2020, 37, 123-134.e5. [CrossRef] [PubMed]

43. Napoli, J.L. Cellular retinoid binding-proteins, CRBP, CRABP, FABP5: Effects on retinoid metabolism, function and related diseases. Pharmacol. Ther. 2017, 173, 19-33. [CrossRef]

44. Nieto, L.; Fuertes, M.; Rosmino, J.; Senin, S.; Arzt, E. Crosstalk of BMP-4 and RA signaling pathways on Pomc gene regulation in corticotrophs. J. Mol. Endocrinol. 2019, 63, 161-174. [CrossRef] [PubMed]

45. Theodoropoulou, M.; Reincke, M. Tumor-Directed Therapeutic Targets in Cushing Disease. J. Clin. Endocrinol. Metab. 2018, 104, 925-933. [CrossRef] [PubMed]

46. Perez-Castro, C.; Renner, U.; Haedo, M.R.; Stalla, G.K.; Arzt, E. Cellular and Molecular Specificity of Pituitary Gland Physiology. Physiol. Rev. 2012, 92, 1-38. [CrossRef]

47. Murakami, I.; Takeuchi, S.; Kudo, T.; Sutou, S.; Takahashi, S. Corticotropin-releasing hormone or dexamethasone regulates rat proopiomelanocortin transcription through Tpit/Pitx-responsive element in its promoter. J. Endocrinol. 2007, 193, 279-290. [CrossRef]

48. Caimari, F.; Korbonits, M. Novel Genetic Causes of Pituitary Adenomas. Clin. Cancer Res. 2016, 22, 5030-5042. [CrossRef]

49. Jin, L.; Riss, D.; Ruebel, K.; Kajita, S.; Scheithauer, B.W.; Horvath, E.; Kovacs, K.; Lloyd, R.V. Galectin-3 Expression in Functioning and Silent ACTH-Producing Adenomas. Endocr. Pathol. 2005, 16, 107-114. [CrossRef]

50. Thodou, E.; Argyrakos, T.; Kontogeorgos, G. Galectin-3 as a marker distinguishing functioning from silent corticotroph adenomas. Horm. 2007, 6, 227-232.

51. Ponnusamy, M.P.; Seshacharyulu, P.; Lakshmanan, I.; Vaz, A.P.; Chugh, S.; Batra, S.K. Emerging role of mucins in epithelial to mesenchymal transition. Curr. Cancer Drug Targets 2013, 13, 945-956. [CrossRef]

52. Mori, Y.; Akita, K.; Yashiro, M.; Sawada, T.; Hirakawa, K.; Murata, T.; Nakada, H. Binding of Galectin-3, a $\beta$-Galactoside-binding Lectin, to MUC1 Protein Enhances Phosphorylation of Extracellular Signal-regulated Kinase 1/2 (ERK1/2) and Akt, Promoting Tumor Cell Malignancy*. J. Boil. Chem. 2015, 290, 26125-26140. [CrossRef]

53. Leung, B.; Lismaa, T.P.; Hort, Y.J.; Turner, J.; Sheehy, J.P.; Ho, K.K.Y. Galanin in human pituitary adenomas: Frequency and clinical significance. Clin. Endocrinol. 2002, 56, 397-403. [CrossRef]

54. Grenbäck, E.; Bjellerup, P.; Wallerman, E.; Lundblad, L.; Anggård, A.; Ericson, K.; Aman, K.; Landry, M.; Schmidt, W.E.; Hökfelt, T.; et al. Galanin in pituitary adenomas. Regul. Pept. 2004, 117, 127-139. [CrossRef] [PubMed]

55. Ibañez-Costa, A.; Rivero-Cortés, E.; Vázquez-Borrego, M.C.; Gahete, M.D.; Jiménez-Reina, L.; Venegas-Moreno, E.; De La Riva, A.; Arráez, M.Á.; González-Molero, I.; Schmid, H.A.; et al. Octreotide and pasireotide (dis)similarly inhibit pituitary tumor cells in vitro. J. Endocrinol. 2016, 231, 135-145. [CrossRef] [PubMed]

56. Hu, J.; Song, H.; Wang, X.; Shen, Y.; Chen, F.; Liu, Y.; Li, S.; Wang, Y.; Shou, X.; Zhang, Y.; et al. Gene expression profiling in human null cell pituitary adenoma tissue. Pituit. 2007, 10, 47-52. [CrossRef] [PubMed]

57. Hamzehzadeh, L.; Caraglia, M.; Atkin, S.L.; Sahebkar, A. Dickkopf homolog 3 (DKK3): A candidate for detection and treatment of cancers? J. Cell. Physiol. 2018, 233, 4595-4605. [CrossRef]

58. Habuta, M.; Fujita, H.; Sato, K.; Bando, T.; Inoue, J.; Kondo, Y.; Miyaishi, S.; Kumon, H.; Ohuchi, H. Dickkopf3 (Dkk3) is required for maintaining the integrity of secretory vesicles in the mouse adrenal medulla. Cell Tissue Res. 2019, 379, 157-167. [CrossRef]

59. Sjöstedt, E.; Bollerslev, J.; Mulder, J.; Lindskog, C.; Pontén, F.; Casar-Borota, O. A specific antibody to detect transcription factor T-Pit: A reliable marker of corticotroph cell differentiation and a tool to improve the classification of pituitary neuroendocrine tumours. Acta Neuropathol. 2017, 134, 675-677. [CrossRef]

60. Øystese, K.A.; Casar-Borota, O.; Normann, K.R.; Zucknick, M.; Berg, J.P.; Bollerslev, J. Estrogen Receptor $\alpha$, a Sex-Dependent Predictor of Aggressiveness in Nonfunctioning Pituitary Adenomas: SSTR and Sex Hormone Receptor Distribution in NFPA. J. Clin. Endocrinol. Metab. 2017, 102, 3581-3590. [CrossRef]

61. Kolnes, A.J.; Øystese, K.A.; Dahlberg, D.; Berg-Johnsen, J.; Niehusmann, P.; Pahnke, J.; Bollerslev, J.; Jørgensen, A.P. Cut-off values for sufficient cortisol response to low dose Short Synacthen Test after surgery for non-functioning pituitary adenoma. Acta Neurochir. 2020, 162, 845-852. [CrossRef] 
62. Fleige, S.; Pfaffl, M.W. RNA integrity and the effect on the real-time qRT-PCR performance. Mol. Asp. Med. 2006, 27, 126-139. [CrossRef]

63. Normann, K.R.; Øystese, K.A.; Berg, J.P.; Lekva, T.; Berg-Johnsen, J.; Bollerslev, J.; Olarescu, N.C. Selection and validation of reliable reference genes for RT-qPCR analysis in a large cohort of pituitary adenomas. Mol. Cell. Endocrinol. 2016, 437, 183-189. [CrossRef] [PubMed]

64. Bolger, A.M.; Lohse, M.; Usadel, B. Trimmomatic: A flexible trimmer for Illumina sequence data. Bioinform. 2014, 30, 2114-2120. [CrossRef]

65. Kim, D.; Pertea, G.; Trapnell, C.; Pimentel, H.; Kelley, R.; Salzberg, S.L. TopHat2: Accurate alignment of transcriptomes in the presence of insertions, deletions and gene fusions. Genome Biol. 2013, 14, R36-13. [CrossRef]

66. Langmead, B.; Salzberg, S.L. Fast gapped-read alignment with Bowtie 2. Nat. Methods 2012, 9, 357-359. [CrossRef] [PubMed]

67. Trapnell, C.; Roberts, A.; Goff, L.; Pertea, G.; Kim, D.; Kelley, D.R.; Pimentel, H.; Salzberg, S.L.; Rinn, J.L.; Pachter, L. Differential gene and transcript expression analysis of RNA-seq experiments with TopHat and Cufflinks. Nat. Protoc. 2012, 7, 562-578. [CrossRef] [PubMed]

68. Goff, L.A.; Trapnell, C.; Kelley, D. CummeRbund: Visualization and Exploration of Cufflinks High-throughput Sequencing Data. Available online: https://bioconductor.statistik.tu-dortmund.de/packages/3.1/bioc/ vignettes/cummeRbund/inst/doc/cummeRbund-manual.pdf (accessed on 28 June 2018).

69. Szklarczyk, D.; Gable, A.L.; Lyon, D.; Junge, A.; Wyder, S.; Huerta-Cepas, J.; Simonovic, M.; Doncheva, N.T.; Morris, J.H.; Bork, P.; et al. STRING v11: Protein-protein association networks with increased coverage, supporting functional discovery in genome-wide experimental datasets. Nucleic Acids Res. 2018, 47, D607-D613. [CrossRef] [PubMed]

70. Thomas, P.D.; Campbell, M.J.; Kejariwal, A.; Mi, H.; Karlak, B.; Daverman, R.; Diemer, K.; Muruganujan, A.; Narechania, A. PANTHER: A Library of Protein Families and Subfamilies Indexed by Function. Genome Res. 2003, 13, 2129-2141. [CrossRef]

71. Galili, T.; O'Callaghan, A.; Sidi, J.; Sievert, C. heatmaply: An R package for creating interactive cluster heatmaps for online publishing. Bioinform. 2017, 34, 1600-1602. [CrossRef]

72. Sievert, C. Interactive Web-Based Data Visualization with R., Plotly, and Shiny; Chapman and Hall/CRC: Boca Raton, FL, USA, 2019; ISBN 9781138331457. Available online: https://plotly-r.com/ (accessed on 12 July 2019).

(C) 2020 by the authors. Licensee MDPI, Basel, Switzerland. This article is an open access article distributed under the terms and conditions of the Creative Commons Attribution (CC BY) license (http://creativecommons.org/licenses/by/4.0/). 